\title{
How is the Daily Shopping Behaviourof Consumer Goods Influenced by Gender
}

\author{
Alena Kusá, Tomáš Fašiang, Petra Grešková \\ The Faculty of the Mass media communication, The University of SS. Cyril and Methodius in Trnava, J. Herda square 2, 91701 \\ Trnava, The Slovak Republic \\ \{tomas.fasiang \& petra.gresko\}@gmail.com, alena.kusa@ucm.sk
}

\begin{abstract}
The consumer shopping behaviour represents the dynamic and the constantly evolving system. The market is still more heterogeneous and consumers, influenced by the external and internal factors, alter more quickly than ever before. The market segmentation to smaller consumer entities appears as a necessity, as the trend of the marketing proceeds to the mass and individual customizing. Taken into account, these match the marketing and communication strategies more precisely. The main aim of the paper is to point on differences in consumer behaviour. We present the marketing study results focusing on the identification of the selected consumer behaviour factors determined by the female and male target audience by the consumer goods of daily use shopping. The result of marketing study is to identify consumer behaviour factors which influence on process of consumer behaviour and based on these is possible to observe differences in males and females when shopping for consumer goods of daily use shopping.
\end{abstract}

Index Terms - consumer, shopping behaviour, gender nuances, shopping behaviour model, retail.

\section{Introduction to the Consumer Shopping Behaviour}

Marketing in the modern terminology and in the competitive environment serves as the inevitable system, which is used to create strategies to satisfy customer needs and achieve the set goals. Based on this, marketing is no longer generally oriented to the whole society. On the contrary, it is still more diversified, devided into several segments, even subsegments, in which the companies should apply their tailor made consumer strategies. Kusá and Hrabovčáková say that the continuous microsegments identification gives the pressure on the brands and changes the common efficiency and the business success schemes. Therefore, the consumer behaviour research experts use the marginal methods to observe the consumer behaviour. These methods should be performed in accordance with the ethical and sustainable economy development principals. [1]

A frequent research has been recently done in order to observe the consumer shopping behaviour in the current society. The research outcome reveals more possibilities that should be used to identify a certain consumer segment. This kind of the shopping behaviour research is complex as the buying process consists of several internal and external factors that are interconnected and not clearly separated. Č́byová states the significant influence of the media communication on the consumers. [9]

\section{Different Approach to the Consumer Behaviour Models}

The consumer behaviour is an important and ongoing decision-making process that includes searching, shopping, assessing and disposing of the products and services. According to the Spilková and Dzúrová [2], three groups of the consumer behaviour approaches should be defined:

1.Psychological approach: emphasizes the mental influence of the consumer. It is claimed that the consumer behaviour is determined by the experience and knowledge.

2.Sociological approach: tries to identify different situations influencing the consumer behaviour.

3. Economy approach: based on the economy principals. The consumers form the sources used to satisfy their requests and needs.

Hes and Pavlů [3] state: "Consumer and company interests are met on the market and traded for market prices". However, it is inevitable to maximize the benefit by chosen combination of the goods and services with minimal initial expenses. [4]

All the mentioned approaches are described in the consumer models. Several authors already dealt with this issue: Kotler, 2007, Shiffman a Kanuk, 2004, Vysekalová, 2008, Hes, 2009 and others. The main idea of the model is to anticipate the consumer action. Moreover, it serves to identify the parameters that determine the buying decision and their correlation. [5]

The consumer behaviour is determined by the whole process of the shopping, from the consumer definition of the need to the purchase evaluation. In order to identify the consumer behaviour, we need to understand the whole shopping behaviour process first. Once the consumer goods of daily use shopping behaviour is known, we should proceed to identify the key factors of the buying decision process, which should be influenced by the communication strategy directly at the points of sale.

\section{Gender Distinction of the Shopping Behaviour}

Based on the topic of the article, we introduce partial studies that deal with the shopping behaviour distinctions determined by the gender of the consumer. As far as the shopping behaviour and buying decision are concerned, there are significant differences between genders. These differences are related to the sociological and biological specifications, 
information process, approach to giving gifts and attitudes to the point of sale atmosphere. [6]

Brand loyalty and motivators reflect also the distinct social interaction approach by both genders. Women are more emotional oriented that is obvious at POS and brand preference. [7] Women unlike men are more sensitive to the hedonistic value and their satisfaction is related to the interaction at product offer, pleasant environment and shopping experience. What is more, women scaled the atmosphere of the POS higher than men. It should be assumed that visual communication, graphics, lights, music, scents are factors more important for women and their overall POS rate. [6]

As far as the tiny esthetical elements (decoration and entertainment) on the POS are concerned, significant differences were found. These should be crucial for women and their personal identification with the POS. They score the overall environment more complex than men whose selective perception causes the low significance of the mentioned elements. [8] Although the shopping realised by men has upward trend, their motivation and shopping behaviour is influenced by standard stereotypes - they are focused on the target (to realise the purchase) and they try to shorten the whole process. Men as women also look for the information and evaluate the product variables. However, they tend to do the process more effective and so use more assertive strategies. Women rely on the interaction and personal contacts. [9]

There are also other factors determined by the community preference. Women are more loyal to the local dealers than men. Women also put higher effort and time to maximise the purchase benefits. Similar attitudes were defined while examining the queues at the cash desk. Men are very negative to the queues, which is therefore reflected in the complex POS atmosphere rate. On the other hand, this factor is not so crucial for women as for men. While measuring the time necessary to spend in the queues, women were much less precise and tend to underestimate the data. [7]

\section{Research Resources}

In order to identify the shopping behaviour of the chosen target groups, it is suitable to specify the shopping potential of the slovak households determined by the macroeconomy indicator - household consumption. [10]

We use 2010-2014 quartal data comparison provided by the Statistical Office of SR as a source for this article. The household consumption indicator determines the total household consumption given by the GDP expenditure methodology. It takes into account the household expenditures spent on the consumer goods and services purchase. In 2014, the overall household expenditures reached 41,7 billion $€$, which means that the average household spends in Slovakia are on the level $1830 €$ monthly (data aggregated based on the population census realised in 2011).

The Fig. 1 refers to the basic index of the selected economy indicators. The index compares the quartal GDP evolution with the household consumption. (Year 2010 is set as a basis) The household consumption shows the upward trend year on year. This positively influences the GDP growth and possible standard of living improvement. [11]

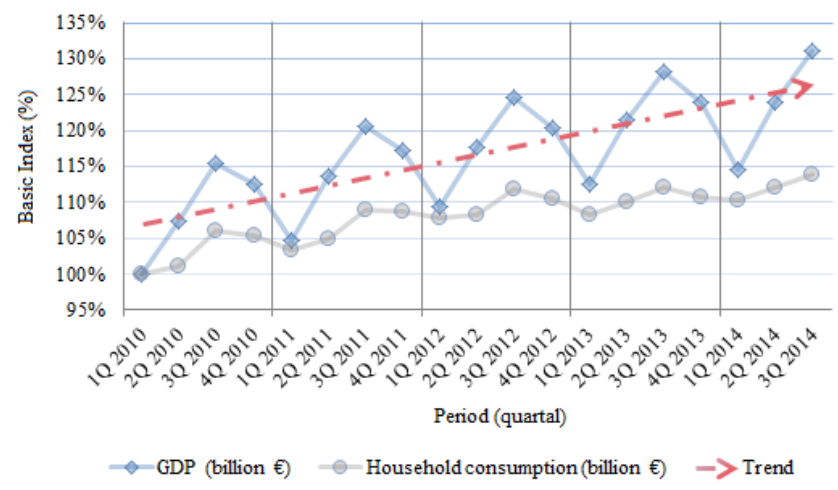

Fig. 1 Index of the selected macroeconomy indicators

Based on the information mentioned previously, the target groups were chosen according to the criteria dealing with the income level of the main purchaser and the level of expenditures dedicated to the main purchase. The main purchase is defined as the major supply of the goods of daily use that serves to satisfy the biological needs of the whole household. When applied on the sample, two target audiences were identified - men and women aged 31-40 years (further used as target audience men and women).

\section{Research Outcomes}

This article presents the research outcomes focusing on the target audience - men and women, and identification of the consumer behaviour factors. The study focuses on the consumer behaviour analysis while doing shopping of the goods of daily use. To ensure the study relevance, the sample of 385 respondents was set. The quota sample selection took into account two main factors - sex and age of the respondents. The data source used to explain the research outcomes goes along with the study topic. The research results reflect the sample that consists of 48 women aged 31 to 40 and 44 men aged 31 to 40 . The consumers of both selected target groups are slovak urban residents with high school education.

Based on the average income comparison of both target groups, we should assume high consumption rate in male target group and therefore higher expenditures dedicated to consumer goods purchase. Women spend $170 €$ on consumer goods purchases in monthly average. On the contrary, men only $163 €$. Therefore, men do no show higher consumer goods consumption trend as predicted. Other outcomes show the important factors determining the POS preferences identified by women: price $(48,0 \%)$, product quality $(24,0 \%)$, product range $(14,0 \%)$ and location $(10,0 \%)$. Men identified the following factors as important to choose POS: price $(51,1 \%)$, quality $(24,4 \%)$ and product range $(15,6 \%)$. These shares represent the most important factors mentioned by the group on the first and second place, i.e. the sum of the shares is not $100 \%$ ). The Fig. 2 below shows the distance and skew of 
certain factors. The longer the distance and the steeper the skew, the more important is the factor in the POS preference. The highest significance is put on the price as number one factor in the POS preference decision. The quality of the products is considered as the second most important factor.

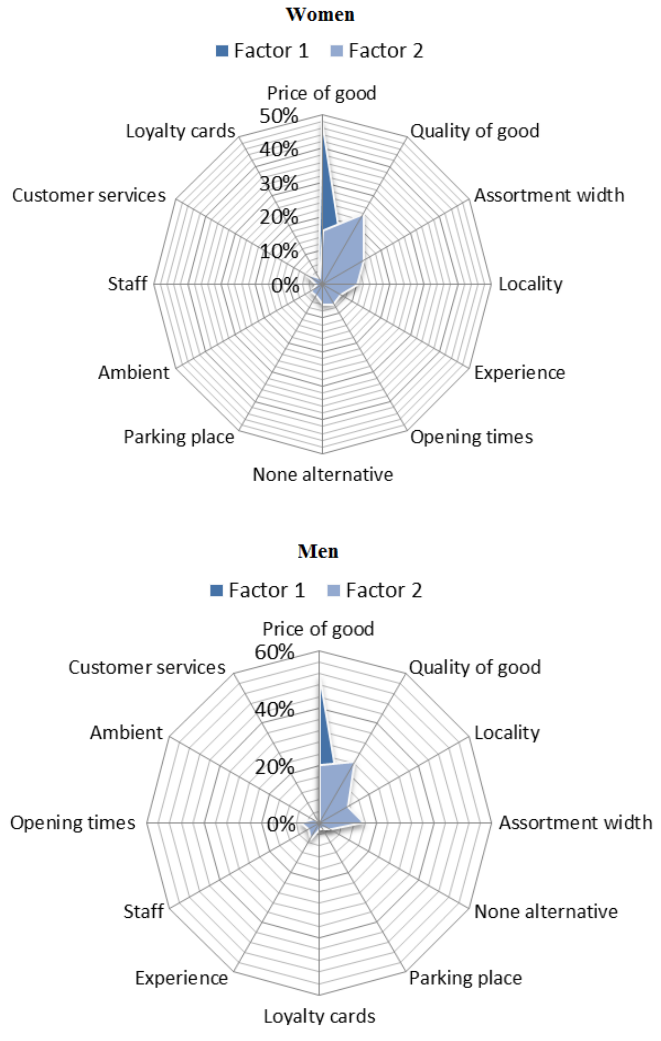

Fig. 2 Attributes of the POS preference

The purchase frequency also indicates nuances determined by the sex. Men do the main shopping of the goods of daily use once a week in average. Other smaller purchases are realised in order to obtain missing goods, which are bought when necessary. There are also individuals who prefer more smaller purchases several times per week. Women mostly prefer smaller purchases several times per week $(46,7 \%)$. The rest of the female target group realizes one main purchase once a week. The missing goods is bought when necessary. Women choose the POS in the distance of $0,5-1 \mathrm{~km}$. Men declared 1,1 to $5 \mathrm{~km}$ distance to do the shopping in their preferred POS. When compared in detail, men usually overcome the distance of 2,2 km in average. On the contrary, women are less willing to commit to their preferred POS. The declared distance is 0,7 $\mathrm{km}$ shorter than the one declared by male target audience. This is related to the issue of the shopping centres placement in the suburbs. The majority of the respondents do the shopping on Fridays, Wednesdays (women) and Saturdays (men).

The retail trade revenues indicate the trend of increasing consumption on the work-free days. [12] Not only the buying decision, but also the use of the purchased products in the household is important in the consumer behaviour definition.
The Table I. shows the fact that the majority of female target group $(51,1 \%)$ decides about the bought products, $37,8 \%$ of women decide about the half. The rest is responsible for less than half of the products obtained for the whole household. $54,5 \%$ men decide about the half of the purchases.

TABLE I The purchase decision

\begin{tabular}{|l|c|c|}
\hline & Women & Men \\
\hline Decide about majority of the purchases & $51,1 \%$ & $17,2 \%$ \\
\hline Decide 50:50 & $37,8 \%$ & $54,5 \%$ \\
\hline Decide about minority of the purchases & $11,1 \%$ & $28,3 \%$ \\
\hline
\end{tabular}

The following Table II. shows the daily products use by all monitored respondents. $22,7 \%$ of men do the shopping to satisfy their own needs, $15,9 \%$ supply the whole household and the majority of them, $61,4 \%$, do the shopping on the passive use purpose. It means that they supply the household with the products, which are then under responsibility of another household member. In comparison, more than half of the female target group (60\%) takes care of the whole household, $28,9 \%$ of women do the shopping to satisfy their own needs and the rest, 11,1\% declared the aim of the passive use of the products.

TABLE II The use of the goods

\begin{tabular}{|l|c|c|}
\hline & Women & Men \\
\hline To satisfy own needs & $28,9 \%$ & $22,7 \%$ \\
\hline Supply the whole household & $60,0 \%$ & $15,9 \%$ \\
\hline Passive use & $11,1 \%$ & $61,4 \%$ \\
\hline
\end{tabular}

To sum up, the purchases of both target groups are influenced by the POS retail techniques. The majority of both target groups $(66,0 \%$ women, $62,2 \%$ men $)$ showed the willingness to buy not only the planned products, but also some products they did not intend to buy. The research results also indicated the positive influence of the promotions on the POS on the final buying decision. $(58,0 \%$ share of women and $53,3 \%$ of men).

Another part of the research dealt with the information sources used by both target groups while doing the shopping.

The value of information consist of time dimension and perception of the consumer. [13] The Fig. 3 shows the information sources (TV, press, radio, and internet) and their share in the target group decision making process. Women are mostly influenced by the TV. Besides TV, internet plays a significant role as the source of the information in male target group. In this context, the media present fundamental functions: informational, educational, entertaining, cultural one, etc. [14] 


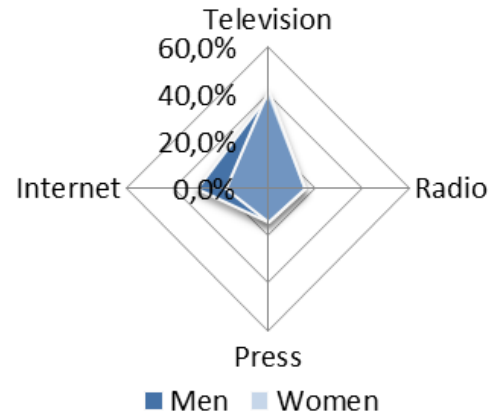

Fig. 3 Information source

\section{Conclusion}

In order to achieve the set marketing goals, it is inevitable to recognise the motives of the consumer behaviour and the factors that influence the buying decision. The studies focused on the consumer behaviour, preferences and decision making process of the purchases belong to the most dynamic marketing sections. This report identified selected factors that determine the behaviour of the consumers aged $31-40$ when doing shopping of the goods of daily use. The study compared the results based on the gender discrepancies and confirmed these differences in male and female shopping approach.

The results of this study serve as an important information source. It is necessary for the retail segment to recognize the factors influencing the consumer behaviour in order to increase flexibility in their market reactions. This leads to the communication strategy adjustment and development of the appropriate approach to the customers.

\section{Acknowledgment}

This article is a partial outcome of the VEGA project no.1/0283/15 ,Aspects of marketing communication in customer's value process creation at B2C market in context with maximization of market share in retail gravity.“

\section{References}

[1] Kusá, A., Hrabačková, V.: Ženy - spotrebitel'ky : Predikčné modely nákupného správania. 1. issue - Trnava : The University od SS. Cyril and Methodius in Trnava, The Faculty of the Mass media communication, 2012. 138 p. ISBN 978-80-8105-432-7.

[2] Spilková, J., Dzurová, D.: Life style changes and risk behavior among Czech teenagers. Procedia - Social and Behavioral Sciences 50, 614-622. [online]. [q. 2015-01-22].

Available online:

<http://www.sciencedirect.com/science/article/pii/S1877042812032028. $>$

[3] Hes, A., Pavlů, D.: Determinanty rozvoje vnitřního obchodu. Praha: Powerprint. 2012. 181 p. ISBN 978-80-87415-58-0.

[4] Hes, A., Šálková, D.: Aspekty chování spotrebitelů pri nákupu potravin. In Communication Today 1/2010 p.125-132. ISSN 1338-130X.

[5] Hes, A. a kol.: Chování spotřebitele při nákupu potravin. 1 issue. Prague: Alfa, 2009. 160 p. ISBN 978-80-871-9720-2.

[6] Granot, E., Greene, H, Brashear, T.: Femaleconsumers: Decision-making in brand-driven retail. In: Journal of Business Research. [online]. 2010, vol. 63, no.8. [q. 2012-02-22].

Available online:

<http://argo.cvtisr.sk:2057/science/article/pii/S0148296310000883>. ISSN 01482963.

[7] Grewal, D. a kol.: The effects of wait expectations and store atmosphere evaluations on patronage intentions in service-intensive retail stores. In: Journal of Retailing. [online]. 2003, vol.79, no.4. [cit. 2012-02-22]. Available online:

<http://argo.cvtisr.sk:2057/science/article/pii/S0022435903000575>. ISSN 0022-4359.

[8] Antonides, G., Van Raaij, W.F.: Consumer behaviour. Rotterdam: John Willey \& Sons, 1998. 619 p. ISBN 0-471-97513-3.

[9] Čábyová, L': Marketing a marketingová komunikácia v médiách - 1. issue - Łódź : Księży Młyn Dom Wydawniczy Michał Koliński, 2012. 211 p. ISBN 978-83-7729-181-8.

[10]Fašiang, T.: Connection Of Chosen Economical Indicators With Development Of Medial Expenses In Non Specified Retail Segment. In Communication Today 1/2012 p.84-96. ISSN 1338-130X.

[11] Statistical Office of the Slovak Republic. 2010-2014. Ukazovatele ekonomického vývoja SR. [online]. 2014. [cit. 2014.01.12] Available online:

$<$ http://www.statistics.sk/pls/elisw/MetaInfo.explorer?cmd=go\&s=1003\& $\mathrm{sso}=3 \& \mathrm{so}=81>$

[12]Č́ábyová, L., Fašiang, T, Kollárová, D., Mužíková, D.: Sunday christian significance and the saints days shopping behaviour. In: European Journal of Science and Theology. 2014, vol. 10, no.1. p. 43 -54. ISSN 1841-0464.

[13]Kupec, V., Kretter, A.: Measurement of Marketing Data Attributes. In Communication Today 1/2013 p.106-116. ISSN 1338-130X.

[14]Matúš, J.: Media and Culture. In: European Journal of Science and Theology. 2014, vol. 10, suppl.1. p. 93 -98. ISSN 1841-0464. 